

\title{
Will Future Immigration to Sweden Make it Easier to Finance the Welfare System?
}

Jan Ekberg

\section{To cite this version:}

Jan Ekberg. Will Future Immigration to Sweden Make it Easier to Finance the Welfare System?. European Journal of Population / Revue européenne de Démographie, 2011, 27 (1), pp.103-124. 10.1007/s10680-010-9227-5 . hal-00608028

\section{HAL Id: hal-00608028 \\ https://hal.science/hal-00608028}

Submitted on 12 Jul 2011

HAL is a multi-disciplinary open access archive for the deposit and dissemination of scientific research documents, whether they are published or not. The documents may come from teaching and research institutions in France or abroad, or from public or private research centers.
L'archive ouverte pluridisciplinaire HAL, est destinée au dépôt et à la diffusion de documents scientifiques de niveau recherche, publiés ou non, émanant des établissements d'enseignement et de recherche français ou étrangers, des laboratoires publics ou privés. 
EUJP269R2

Will future immigration to Sweden make it easier to finance the welfare system?

Jan Ekberg is professor of economics at the Centre of Labour Market Policy Research (CAFO), School of Management and Economics, Linneaus University, Växjö, Sweden.

e-mail: Jan.Ekberg@lnu.se

JEL classification: F22, J15, H5

Acknowledgements I am grateful to the Expert Group on Public Finance (ESO) at the Ministry of Finance, Sweden, for financial support of this study. I am also grateful for useful comments and suggestions from two anonymous referees and from the editor, from ESO's reference group, from Ali Ahmed and Lennart Delander Linnaeus University Växjö, and from Christer Gerdes Stockholm University and Martin Ådahl Fores. Besides I am grateful to Annika Klintefelt, Petter Lundborg, Hans Lundström and Petter Wikström at Statistics Sweden for excellent data. 


\begin{abstract}
Will future immigration to a country with a large public sector alleviate the increasing burden on the public welfare system due to an ageing population? The question is based on the experience that the age structure of immigrants differs from that of the native population. Fiscal impacts due to immigration depend mainly on the size, the age composition and the labour market integration of the additional population which arises because of immigration. A projection from Statistics Sweden about future immigration combined with the latest Long Term Survey of the Swedish Economy has been used in this study. Calculations for Sweden up to the year 2050 show that the positive net contribution to the public sector from the additional population is rather small even with good integration into the labour market. The reason is that future immigration will increase the size of the population and thereby raise not only revenue from taxation but also public expenses. The fiscal impact is sensitive to the labour market integration of the additional population. The yearly positive/negative net contribution effect is less than $1 \%$ of GDP for most of the years. On the whole, the results are about the same even if we change the assumptions concerning the composition of future public revenues, the growth of public expenses, return migration, or the age-specific birth and death rates in the additional population. More considerable net fiscal effects would require a much higher and probably unrealistic level of future immigration.
\end{abstract}

Key words: Immigration, public sector, age structure, additional population, employment 


\section{En Suède, l'immigration future pourra-t-elle faciliter le financement du système de sécurité sociale?}

L'immigration future dans un pays disposant d'un vaste secteur public soulagera-t-elle le poids que le vieillissement démographique fait peser sur le système public de sécurité sociale? La question se base sur le fait que la structure par âge des immigrants diffère de celle de la population autochtone. L'impact fiscal de l'immigration dépend principalement de l'importance numérique, de la structure par âge et de l'intégration dans le marché du travail de la population additionnelle qui survient du fait de l'immigration). Une projection relative à l'immigration future réalisée par Statistiques Suède combinée aux données de la dernière enquête de longue durée sur l'économie suédoise a été utilisée pour cette étude. Les projections jusqu'en 2050 montrent que la contribution positive nette de la population additionnelle au secteur public est plutôt faible même dans le cas d'une bonne intégration dans la marché du travail. Ceci est dû au fait que l'immigration future augmentera l'effectif de la population, accroissant ainsi les revenus issus des taxes mais aussi les dépenses publiques. L'impact fiscal est sensible au degré d'intégration de la population additionnelle dans le marché du travail. La contribution annuelle nette positive/négative est inférieure à $1 \%$ du PIB pour la plupart des années considérées. Dans l'ensemble, les résultats restent semblables quelles que soient les hypothèses relatives à la composition des recettes publiques futures, à la croissance des dépenses publiques, aux migrations de retour et aux taux de natalité et de mortalité par âge de la population additionnelle. Des effets fiscaux plus élevés nécessiteraient des niveaux d'immigration future beaucoup plus élevés et sans doute irréalistes.

Mots-clés: Immigration - Secteur public - Structure par âge - Population additionnelle Emploi 


\section{Introduction}

Many Western countries are facing a demographic development that will increase the burden on their public finances. This is also the case for Sweden. At present, the sum of yearly public expenses in Sweden is about 50\% of the gross domestic product (GDP). The yearly public expenses solely for the welfare system exceed 30\% of GDP. According to the Swedish Audit Bureau (2007), the yearly public expenses will increase to about $60 \%$ of GDP in 2030 due to an ageing population. Will immigration in the future ease the pressure on public finances? For the present, this issue furnishes matter for much political debate. The question is based on the experience that the age structure of the immigrant population differs from that of the native population, with a lower proportion of old people and a higher proportion of people of working age. This has been the case in Sweden over the entire post-war period, be it for labour immigration or the immigration of refugees and their relatives (Statistics Sweden 2004). The situation seems also to be the same in other immigration countries.

There are two factors of special importance for determining whether future immigrants will make a positive or a negative net contribution to the public sector. The first is the difference in age distribution between immigrants and natives, the second is the difference in their respective employment situations. If the immigrants contribute more/less in taxes and social security fees than what they receive from the public sector there will be a positive net/negative net contribution to the public sector.

The public sector in Sweden functions as a pay-as-you-go system. The yearly expenditures are financed by taxes and social security fees paid during the same year. Heavy public consumption expenditures are directed to the young (child care and education), and especially to the older population (healthcare, service for pensioners and disabled). Even public transfer payments go largely to old people (pensions). The tax burden is mainly carried by employed people. The favourable age structure of immigrants is therefore a major determinant of their net contribution to the public sector. However, a less favourable employment situation among the immigrants relative to that of natives will increase the immigrants' share of certain public expenditures such as social allowances, unemployment benefits, and expenses for labour market programmes. It will also decrease their share of contributions to taxes and social security fees. Thus, a low employment rate will counterbalance the fiscal effects of the immigrants' favourable age structure. To what extent this occurs is an empirical question.

The proportion of foreign-born in the Swedish population has increased from about $1 \%$ in 1940 to about $14 \%$ in 2009 . The last figure corresponds to about 1.3 million individuals. Besides, there is a growing group of persons born in Sweden with at least one parent born abroad. This group today comprises nearly 1 million individuals. More than half of them have one parent born in Sweden. There have been major changes in the employment situation of immigrants in Sweden during the last 30 years. The conclusion from many studies, (e.g. Ekberg 1983; Ohlson 1975; Wadensjö 1973), is that the employment situation for immigrants in Sweden was good up to the second half of the 1970s. Both natives and immigrants enjoyed full employment. At the end of the 1970s, however, labour market integration of new immigrants began to deteriorate and since then this tendency has strengthened. However, since late 1990s the situation has improved somewhat and the employment rate of 20-64-yearolds is currently about $20 \%$ lower for foreign-born persons living in Sweden compared to natives (Ekberg 2009). 
Immigration may also affect the income conditions of the natives in other ways than through its fiscal impact. Immigration may influence relative factor prices and employment opportunities for natives. Some groups of natives may lose and others may benefit. There may be a downward pressure on wages and increased unemployment among those who are substitutes to the immigrant labour force and reverse effects for those who are complements. Among those in the domestic population who lose/benefit, the need for public transfer payments may increase/decrease and the payments of state and local taxes may decrease/increase. However, meta-analyses of studies from many countries have found, on average, very small effects on the natives' labour market situation (Longhi, Nijkamp and Poot 2005, 2006, 2008 ). A 1\% increase in immigrants in a country decreases the employment rate for natives by only $0.024 \%$. An increase of one percentage unit in the share of immigrants in the workforce may reduce wages for natives by only $0.1 \%$. In Sweden likewise, these effects are small (Korpi 2008). In the long term, once the labour market has adjusted, the consequences of immigration for the natives' opportunities on the labour market seems to be rather negligible. The redistribution effect between labour and capital due to immigration also seems, on average, to be small (Ben-Gad 2004). The same result is found for Sweden (Ekberg 1983). Thus, there is no reason to believe that the post-war immigration to Sweden has had such strong effects that the natives' use of and contributions to the public sector have been significantly affected. It is reasonable to assume that effects of future immigration will not differ in this respect.

The aim of this article is to find out to what extent future immigration to Sweden will make it easier to finance the welfare system for an ageing population. A recent forecast of the Swedish population and of the size and composition of future migration to Sweden up to 2050 (Statistics Sweden 2006) has been used in this study. We have linked this forecast to the predicted future development of the Swedish economy and the public sector according to the latest Long-Term Survey of the Swedish economy (Ministry of Finance 2008a, 2008b).

The present study departs from previous ones in two important respects. Firstly, we consider the additional population due to forecasted immigration from 2006 up to 2050 . The predicted additional population in a specific year in the future is the result of immigration from 2006 and the following years, later out-migration, and age-specific birth rates and death rates among immigrants and their descendants. The subsequent ageing process among those who immigrate is more or less counterbalanced by the fact that descendants of immigrants are also born in Sweden. Most earlier studies have considered only those who immigrate and are limited either to foreign citizens or to foreign-born individuals and have conducted crosssectional investigations for one or a few years. Other studies follow a cohort of immigrants over time. Considering the additional population is a third approach. The long-term economic effects of immigration such as effects on labour supply, on public expenses and contributions to the public sector depend on the size, age composition and labour market integration of the additional population due to immigration. Therefore it is important to consider, as we do here, the long-term demographic effects due to immigration. Secondly, we combine a demographic model with a model for calculating the stream of future tax payments, social security fees and public expenditures connected with the additional population.

The paper proceeds in the following way: Section 2 presents some previous research on fiscal effects of immigration; Section 3 describes the data used in this study; the results are presented in section 4 and the sensitivity analyses in section 5. The conclusion is given in section 6 . 


\section{Previous research}

The results from earlier studies of fiscal effects due to immigration are ambiguous. This is probably due do some basic circumstances such as: a) many studies do not include all relevant fiscal items, b) the quality of data varies strongly from one country to another, c) different studies cover different periods, d) the definition of immigrants varies. Most investigations are empirical, some are simulation studies.

For USA, Simon (1984), found a positive net fiscal effect due to immigration, Blau (1984) found a neutral fiscal effect and Weintraub (1984) a negative net fiscal effect for the big cities. Borjas (1994) concluded that there was an increase over time of public welfare expenses in the US associated with immigrants which may indicate that the net fiscal effect is currently negative. Lee and Miller (2000) found a negative effect soon after immigrants' arrival, but it later turns positive. For Canada, Akbari (1989) found a positive net fiscal effect, as did Kakwani (1986) for Australia, and Straubhar and Weber (1994) for Switzerland. For Germany, Gieseck, Heileman and Loeffelholz (1994) found a positive net fiscal effect, as did Ulrich (1994). For Germany, Bonin, Raffelhuschen and Walliser (2000) calculated the net fiscal effect associated with future immigration. They found that there will be a positive effect if future immigrants' economic characteristics are like those of immigrants already living in Germany. However, the positive effect will be small and not enough to alleviate the burden on the public sector due to an ageing population. For Denmark, Wadensjö (2000) and Wadensjö and Orrje (2002) found a negative net fiscal effect estimated to nearly $1 \%$ of GDP per year. The result for Denmark is in line with results for Sweden, see below, when we consider that the proportion of foreign-born in Denmark is about half of the proportion foreign-born in Sweden. Even Pedersen (2002) and Schou (2006) found a negative net fiscal effect for Denmark. The reason is the unfavourable labour market situation for immigrants in Denmark.

In Sweden, a number of studies have been performed (Wadensjö 1973; Ekberg 1983, 1999, 2009; Gustafsson 1990; Gustafsson and Österberg 2001). They conclude that the immigrants made positive net fiscal contributions during the post-war period up to about 1980 . The yearly positive net fiscal effect culminated in about 1970 but was even then rather small and amounted to no more than $1 \%$ of GDP. Since then, the net contribution has decreased because of the worsened labour market situation among immigrants. In the second half of the 1980s, the yearly net fiscal effect was zero and in the beginning of 1990s it was negative and amounted to $0.9 \%$ of GDP, rising to $1.5-2 \%$ of GDP by the end of the 1990s. Since then the situation has stabilised and today the yearly negative fiscal effect is still about $1.5-2 \%$ of GDP even though the immigrant population has increased. The reason is that the immigrants' employment situation has improved somewhat since the end of the 1990s. The age composition of the immigrant population in Sweden is still more favourable than that of the native population. Storesletten (2003) investigated the net fiscal effects of immigration with different assumptions concerning the immigrants' employment rate. The outcome depends very strongly on the extent to which immigrants are integrated into the labour market.

Coleman and Rowthorn (2004) and Rowthorn (2008) reviewed a large number of previous studies from many countries on the fiscal impact of immigration. They found that the net fiscal effect was in general quite small and was, in most countries, in the range of $+/-1 \%$ of GDP. A negative net fiscal contribution was found when immigrants were low-skilled and/or labour market integration was weak. However it is not certain that the net fiscal effects from previous immigration will be the same as from future immigration to countries with a rapidly ageing population. 


\section{Data for the present study}

\subsection{The population development}

In 2006 the population of Sweden was 9.1 million. The additional population in Sweden due to future immigration as from 2006 includes the immigrants' descendants born in Sweden and depends also on death rates and return migration. The population without the additional population is called the original population. In 2015 , the additional population will be about 164,000 individuals, in 2025 about 480,000, in 2035 about 830,000, and in 2050 nearly 1.4 million individuals (Statistics Sweden 2006). ${ }^{1}$ These figures correspond to 1.7\%, 4.7\%, 7.8\%, and $12.4 \%$ of the forecasted Swedish population for the years in question. During the whole period, the additional population has a favourable age composition. The proportion aged 65 years and above is $2.8 \%$ in 2015 and will increase to $10.2 \%$ in 2050 . In the population living in Sweden today the share of persons in that age group is nearly $18 \%$ and increasing. More information is given in Table 1. Even if the immigrant population has a larger share aged 2064 and a lower share of elderly people, the age effect of immigration on the total population is rather small and cannot prevent the total population growing older. The forecasted additional population can only delay this development.

Note that for countries in Europe, future immigration cannot prevent population ageing unless migration inflow is very high and increases over time (Coleman 2008).

Table 1 Age composition in percent in four selected years*.

\begin{tabular}{lllllllllllll}
\hline Age & 2015 & \multicolumn{4}{c}{2025} & \multicolumn{3}{c}{2035} & \multicolumn{1}{c}{2050} \\
& 1 & 2 & 3 & 1 & 2 & 3 & 1 & 2 & 3 & 1 & 2 & 3 \\
\hline $0-19$ & 31.8 & 22.1 & 22.2 & 31.6 & 22.7 & 23.1 & 31.1 & 22.2 & 22.9 & 28.2 & 21.9 & 22.6 \\
$20-64$ & 65.3 & 57.4 & 57.6 & 64.4 & 54.9 & 55.3 & 63.3 & 53.4 & 54.3 & 62.6 & 53.6 & 54.6 \\
$65+$ & 2.8 & 20.5 & 20.2 & 3.9 & 22.4 & 21.6 & 5.7 & 24.4 & 22.8 & 10.2 & 24.5 & 22.8 \\
Total & 100 & 100 & 100 & 100 & 100 & 100 & 100 & 100 & 100 & 100 & 100 & 100 \\
Number & & & & & & & & & & & & \\
Million & 0.16 & 9.36 & 9.52 & 0.48 & 9.63 & 10.11 & 0.83 & 9.75 & 10.58 & 1.40 & 9.83 & 11.23 \\
\hline
\end{tabular}

$1=$ Additional population due to immigration.

$2=$ Population without the additional population (the original population).

$3=1+2=$ Total population.

* More information is given in Appendix Table A.

Sources: Statistics Sweden (2006). Worked up data from Statistics Sweden.

\footnotetext{
${ }^{1}$ In reality, Statistics Sweden (2006) made two forecasts of future immigration. There is one basic alternative and one alternative with higher immigration. The basic alternative corresponds to a yearly net immigration (difference between immigration and outmigration) of 12,000-15,000 individuals. It is not realistic to use a basic alternative with no net immigration at all because this alternative also includes native-born Swedes who return home. In the high immigration alternative, the yearly net immigration is about 35,000 individuals. By future immigration we mean the difference between the high immigration alternative and the basic alternative. The additional population is a projection of this difference considering age-specific fertility rates, age-specific death rates and return migration. The original population is a projection of the rest (the majority) of the population. Thus the original population also includes the immigrants already living in Sweden 2006.

In the forecast it is assumed that the country composition of the future immigrants to Sweden will be approximately $18 \%$ from the other Nordic countries, 18\% from EU 25 (the Nordic countries excluded) and 64\% from the rest of the world.
} 


\subsection{Public expenses}

We have used data from several sources. In the initial year (2006), the sum of public transfers and public consumption expenditures amounted to SEK 1359 billion. $^{2}$ This corresponds to 47\% of GDP in 2006. SEK 597 billion was public transfer payments and SEK 762 billion was public consumption expenditures. All these expenses were financed by taxes and social security fees. For 2006 we have data from the Social Security Statistics for Sweden for nearly $90 \%$ of the public transfer payments to individuals grouped into age classes (Försäkringskassan 2007). Per capita amounts of transfer payments in different age classes are shown in Table 2. For 2006, we have data on national accounts from Statistics Sweden on about $64 \%$ of the public consumption expenditures which can be grouped into age classes. These public consumption expenditures are grouped into age classes using the methods proposed by Ekberg (1999) and Storesletten (2003). Per capita amounts in different age classes are given in Table 3. Other public transfer payments and other public consumption expenditures cannot meaningfully be allocated to age groups. They are non age-dependent and mostly concern transfer payments to companies and consumption expenditures on public goods or mixed public goods. The growth of non age-dependent public expenses depends on a growing population. The growth of age-dependent public expenses depends both on an ageing population and on a growing population.

Table 2 Age-dependent public transfer payments. Per capita amounts 2006. SEK.

\begin{tabular}{lrrrrrrr}
\hline Age & 1 & 2 & 3 & 4 & 5 & 6 & Sum \\
\hline $0-6$ & 110 & - & - & - & 35860 & 1220 & 37190 \\
$7-15$ & 600 & - & - & - & 22300 & 1220 & 24120 \\
$16-19$ & 1290 & 30 & 510 & 9020 & - & 1800 & 12650 \\
$20-24$ & 2050 & 1420 & 3280 & 12560 & 70 & 2380 & 21760 \\
$25-34$ & 2900 & 4420 & 2620 & 10440 & 560 & 2170 & 23110 \\
$35-44$ & 8330 & 7180 & 2840 & 8390 & 970 & 1860 & 29570 \\
$45-54$ & 14550 & 8920 & 2070 & 6770 & 470 & 2260 & 35040 \\
$55-64$ & 34620 & 10770 & 840 & 6700 & 40 & 2830 & 55800 \\
$65-74$ & 134100 & 130 & 100 & 550 & - & 1350 & 136230 \\
$75-$ & 133580 & 130 & 20 & - & - & - & 133730 \\
\hline
\end{tabular}

1: Old-age pension, disability pension, widow's pension, child pension, survivor's pension, part pension, disability allowances and housing benefits to pensioners.

2: Sickness cash benefits, rehabilitation cash benefits and work injury cash benefits.

3: Housing allowances to families with children and social assistance.

4: Unemployment cash benefits and student allowances.

5: Child allowances, parental leave cash benefits, temporary parental leave cash benefits, pregnancy cash benefits and care cash benefits. Parental cash benefits and temporary parental leave cash benefits can be claimed until the child is 12 years old. So, these benefits are distributed in the age class up to 12 .

6: Assistance cash benefits for individuals with functional disorders, allowances for home

\footnotetext{
${ }^{2}$ There are also public investments but they amounted to only about $5 \%$ of public expenses in 2006 . Besides, a large share of public investment is not financed by taxes but by loans. Therefore, we limit public expenses to public transfer payments and public consumption expenditures.
} 
care of a sick family member and allowances to individuals with physical disorders to buy special adapted cars (if they cannot use other transports such as bus or train).

Sources: Försäkringskassan (2007). Worked up data from Statistics Sweden.

Table 3 Age-dependent public consumption expenditures. Per capita amounts 2006. SEK.

\begin{tabular}{lrrrrrrr}
\hline Age & 1 & 2 & 3 & 4 & 5 & 6 & Sum \\
\hline $0-6$ & 8500 & - & 38100 & - & - & - & 46600 \\
$7-15$ & 5900 & 86200 & 12500 & - & - & - & 104600 \\
$16-19$ & 8200 & 77600 & - & - & 3000 & 800 & 89600 \\
$20-24$ & 8200 & 44200 & - & 100 & 4800 & 3100 & 60400 \\
$25-34$ & 8800 & 22700 & - & 300 & 2900 & 1800 & 36500 \\
$35-44$ & 11500 & 2300 & - & 300 & 2400 & 900 & 17400 \\
$45-54$ & 14600 & 1100 & - & 400 & 1800 & 400 & 18300 \\
$55-64$ & 19900 & 500 & - & 3100 & 1600 & 100 & 25200 \\
$65-74$ & 35400 & - & - & 16100 & - & - & 51500 \\
$75-$ & 94800 & - & - & 70600 & - & - & 165400 \\
\hline
\end{tabular}

1: Health care and dental care.

2: Education.

3: Childcare and certain measures for children.

4: Service for pensioners and disabled.

5: Labour market policy measures.

6: Criminal care.

Sources: Statistic Sweden National accounts 2006. Worked up national accounts 2006. 
It is a reasonable assumption that the per capita amounts in Table 2 and Table 3 will increase over time when the economy grows. We have information from the latest Long Term Survey of the Swedish Economy which also assumes future immigration to Sweden (Ministry of Finance 2008a; 2008b). According to the survey, the wage income per gainfully employed person will increase by $2.1 \%$ per year and the public transfer payments will grow by the same percentage to secure the standard of living for individuals supported by the public welfare system. Therefore we assume that the per capita amounts in Table 2 will increase by $2.1 \%$ per year. Besides there is a small share of non age-dependent public transfers to individuals. These transfers are also assumed to increase by $2.1 \%$ per capita per year. Increasing standard of living will probably also increase the demand for public consumption in the population and we therefore assume that the per capita amounts in Table 3 will also increase by $2.1 \%$ per year. The long term survey assumes that GDP will increase by $2.2 \%$ per year.

Conceivably, future pensions to the additional population are somewhat overestimated because the level of old-age pension for an individual depends on the sum of work incomes during their time in Sweden. The sum of these incomes is low for many immigrants who have not lived for many years in Sweden and so their pension amount is low. To some extent this is offset by higher social assistance and housing allowances. However even including these compensations, the public transfers for many old foreign-born persons are lower than for old native-born persons. There is no information in the forecast from Statistics Sweden (2006) about the number of years of future residence in Sweden for individuals in the additional population. However, this is not a big question for the level of the net fiscal contribution of this population because the proportion of retirement pensioners is small during the entire observation period.

Immigrants who have moved back to their home country (or to another country) have the right to a retirement pension when they reach the age of 65 . There is not sufficient information in the immigration forecast from Statistics Sweden about the number of years spent in Sweden by those individuals who leave the country. However, for a long time the amounts paid out have to be very small. In 2015, the immigrant with the longest time spent in Sweden has lived there only 9 years. The time in Sweden would be much shorter for most of those who have immigrated since 2006. Also, for many of those individuals who leave up to 2025 the time in Sweden will probably be short. In the years thereafter, the pension amounts will increase but will probably still be small. As mentioned, we have overestimated the pension amounts for those in the additional population living in Sweden so it is not of significant importance if we cannot consider the small pension amounts paid to those who have moved out.

There are also public transfer payments to companies which are non age-dependent. The amounts are small compared to the public transfers to individuals. The welfare of individuals may indirectly be affected through stimulation of employment and by lower prices on private consumption. There are no data or other information on how the benefits from these subsidies are distributed in the population. We therefore let the share of these transfer payments to the additional population be the same as its share to the total population. Even public transfer payments to companies are assumed to grow by $2.1 \%$ per year.

There are some special public consumption expenditures that exclusively cater to immigrants, i.e. expenses for home-language instruction and for teaching Swedish to adult immigrants. As all young immigrants who go to school are entitled to home-language instruction, expenses for that activity will grow with a growing population of immigrants. With a stable annual 
migration inflow, the yearly expenses for teaching Swedish to adult immigrants will, however, remain about constant. From the national accounts we have exact information about these two kinds of expenses which we can use to calculate these expenses for the future additional population. We let it grow yearly by $2.1 \%$ per capita.

Many other public expenses are expenditures on public goods or mixed goods such as defence, basic research, recreation and culture, the road system, and public administration. Both the additional population and the original population increase over time according to Table 1. To what extent does an increase in population imply a more effective use of these kinds of public utilities and to what extent does it require increased public expenses? To take these questions into consideration we have used two different methods which are described below.

The public expenses for the total population in year $t(E t)$ are:

$$
\begin{aligned}
& E t=\sum_{j} E j t \times N j t+O E t \times N t+\sum_{j} E i j t \times N i j t+O E i t \times N i t \\
& \begin{array}{l}
t= \\
j=0-6,7-15,16-19,20-24,25-34,35-44,45-54,55-64
\end{array} \\
& \quad 65-74,75-
\end{aligned}
$$

Ejt $=$ Sum of age-dependent public transfer payments per capita + age-dependent public consumption expenditures per capita in age class $j$ in year $t$ in the original population.

$N j t=$ Number of individuals in the original population in age class $j$ in year $t$.

$O E t=$ Non age-dependent public transfer payments per capita + non age-dependent public consumption expenditures per capita in the original population in year $t$.

$N t=$ Number of individuals in year $t$ in the original population.

Eijt $=$ Sum of age-dependent public transfer payments per capita + age-dependent public consumption expenditures per capita in age class $j$ in year $t$ in the additional population.

$N i j t=$ Number of individuals in age class $j$ in year $t$ in the additional population.

OEit $=$ Non age-dependent public transfer payments per capita + non age-dependent public consumption expenditures per capita in the additional population.

$N i t=$ Number of individuals in year $t$ in the additional population . 


\subsection{Public revenues}

The public sector is financed by direct taxes, indirect taxes and social security fees. In 2006, the proportions of these revenues were: direct taxes from individuals $32.8 \%$, direct corporate taxes $7.3 \%$, indirect taxes $33.9 \%$ and social security fees $26.0 \%$. According to the latest Long Term Survey of the Swedish Economy there will be only very small changes in these proportions up to 2050 (Ministry of Finance 2008b). ${ }^{3}$ We have taken these changes into account. Besides, we assume the public finances to be balanced in the future, i.e. that the yearly sum of direct taxes, indirect taxes and social security fees will be the same as the yearly sum of public transfers and public consumption expenditures.

\section{Direct taxes}

The Swedish income register includes yearly data about individuals' incomes from work (wages, salaries and self-employment incomes) and capital, how much they receive in public transfer payments, their taxable income and disposable income, and how much they pay in direct taxes. As mentioned above, the incomes from work per gainfully employed person and from capital are assumed to grow by $2.1 \%$ per year. The same growth rate is assumed for the public transfer payments per capita in Table 2. With the help of this information we can, for our prognostication period, calculate the yearly taxable incomes for individuals, how much they will pay in direct taxes and their disposable incomes. How much an individual receives in public transfer payments and how much he or she pays in direct taxes depends primarily on their position on the labour market. Furthermore we assume that for individuals in the additional population aged over 20 the capital income per capita is half of that in the original population aged over 20 . We have no data about capital incomes among descendants to foreign-born persons living in Sweden. However, for the foreign-born there is some information. According to Statistics Sweden (2002a), the capital incomes per capita among foreign-born persons aged over 20 living in Sweden is about half that of natives over 20. We use this information also for the additional and original population. One reason for using a lower amount for the additional population is that it probably takes time to accumulate capital after arrival in Sweden. The exact assumption in this case has no significant importance for our results.

A small share of direct taxes are corporate taxes. It is reasonable to assume that corporate taxes are closely linked to the ownership of capital. As mentioned, we have information about capital incomes which we use to calculate corporate taxes allotted to the additional population.

\section{Indirect taxes}

These taxes are proportional and based on consumption. The consumption expenditures are governed by the individuals' disposable incomes. The disposable income for an individual equals income from work + income from capital + taxable public transfer payments + non taxable transfer payments - income taxes. We assume that the share of indirect taxes for the additional population is the same as their share of disposable incomes in the whole population.

\footnotetext{
${ }^{3}$ For example the proportions will be $34.3 \%, 7.9 \%, 32.4 \%$ and $25.4 \%$ in $2020 ; 34.4 \%, 7.6 \%, 32.7 \%$ and $25.3 \%$ in $2030 ; 34.4 \%, 7.4 \%, 32.7 \%$ and $25.5 \%$ in $2040 ; 34.3 \%, 7.6 \%, 32.2 \%$ and $25.8 \%$ in 2050 . For 2015 we have used the average of the proportions in 2006 and 2020. For 2025 the average of the proportions in 2020 and in 2030 have been used. For 2035 the average of the proportions in 2030 and in 2040 have been used.
} 


\section{Social security fees}

These are proportional. They are based on the sum of work incomes. We can therefore assume that the share of social security fees for the additional population is the same as their share of the sum of work incomes in the whole population.

\section{Two cases and two methods}

In this study, the contributions to the public sector and the public expenses for the additional population will be calculated for two cases. One is optimistic (case 1) and the other pessimistic (case 2) regarding the labour market situation for the additional population. In case 1 we assume that the age-specific employment rates and average age-specific annual work incomes per gainfully employed person are the same for the additional population as for the original population. ${ }^{4}$ The levels in the initial year 2006 are assumed to be the same as for the population living in Sweden in 2006 (Statistics Sweden 2007, 2008a). This is an optimistic case given the present labour market situation for immigrants now living in Sweden. However, a goal for the Swedish integration policy is that immigrants (even refugees) and their descendants should be integrated on the labour market to about the same extent as natives. In the 1950s, 1960s and 1970s, the labour market situation was about the same for foreign-born as for native-born. It is reasonable to assume that the age-specific per capita amount of public transfer payments and public consumption expenditures are also the same for the two groups, i.e. Ejt =Eijt . As mentioned above, we may somewhat overestimate the level of retirement pensions for the immigrant population but this is not a big issue. In this case we also assume that GDP will increase by $2.2 \%$ per year in line with the latest Long Term Survey of the Swedish Economy (Ministry of Finance 2008a).

In case 2, we assume that the employment situation for the additional population is inferior to that of case 1 and postulate age-specific employment rates equal to those of the foreign-born now living in Sweden, i.e. 20\% lower than for native-born persons today (in 2006). This is probably a pessimistic alternative because the position on labour market for descendants of foreign-born persons is much better than for the foreign-born themselves (Ekberg 2009). For the original population, the situation is presumed to be the same as in case 1. Certain public expenses for the additional population such as social allowances, unemployment allowances, housing allowances, and costs for labour market policy programmes are assumed to be much higher than in case 1, i.e. Ejt < Eijt for individuals aged 20-64. According to data from Statistics Sweden (2008a), the per capita amount in the 20-64 age range for social allowances + unemployment allowances + housing allowances was about $90 \%$ higher among foreignborn than among natives (standardised for age) in 2006. The yearly incomes from work per gainfully employed person was somewhat lower for foreign-born than for natives. The unemployment rate was twice as high among foreign-born than among natives. Ekberg and Rooth (2001) found that the share of foreign-born in labour market policy programmes was about the same as their share in the total number of unemployed in the total population. We use these kinds of information for the additional population. Because of the lower incomes from work, we assume that retirement pension per pensioner is $20 \%$ lower in the additional

\footnotetext{
${ }^{4}$ The age-specific employment rates can differ between different immigrant groups. We assume that, on average, the age-specific employment rates are the same in the additional population as in the original population. In the 1950s, 1960s and 1970s, when the labour market situation was good for immigrants in Sweden, the age-specific employment rates were practically the same for different immigrant groups and for refugees.
} 
population than in the original population, i.e. Ejt $>$ Eijt at age 65 and above. The yearly income from work per gainfully employed, public transfer payments and public consumption expenditures per capita are also, in this case, assumed to increase by $2.1 \%$ per year. Because of the worse position on the labour market for the additional population in this case, the yearly level of GDP will be somewhat lower than in case $1^{5}$.

Some public expenses are non age-dependent and consist mostly of expenses for public goods or mixed public goods such as defence, basic research, recreation and culture, road system, and public administration. To what extent does a population growth imply increased expenditures on these kinds of public consumption? Two methods, based on different assumptions, are used to calculate effects of immigration in this respect.

In method 1 we assume that the expenses for non age-dependent public consumption and public transfer payments increase in proportion to the increase in population. The per capita amount for the additional population is assumed to be the same as for the original population and to increase by $2.1 \%$ per year. This method probably overestimates the growth of this kind of public consumption expenditure. For instance, according to the Ministry of Finance (1990) the population increase in Sweden between 1970 and 1990 (more than 0.5 million) did not imply more expenditure for defence.

In method 2, the assumption as regards growth in public transfer payments and age-dependent public consumption expenditures is the same as in method 1. We assume, however, a lower growth in non age-dependent public consumption expenditures. As mentioned, these are mainly expenditures on public goods or mixed goods. The per capita amount for the increased population since the initial year 2006 is assumed to be half of the per capita amount in method 1. Thus, the public sector will be somewhat smaller with method 2 than with method 1 .

\section{Results}

\subsection{Case 1}

The results in case 1 are summed up in Table 4 which shows the yearly fiscal effect in the years 2015, 2025, 2035 and 2050 compared with GDP for these years. The selection of these years is sufficient to give us picture of what will happen over time. There are yearly positive net contributions to the public sector and these contributions as share of GDP increase over time. The main reason is that the additional population grows from about 164000 in 2015 to nearly 1.4 million in 2050. However, the positive fiscal net effects are small during the whole period and less than 1\% of GDP for all years under method 1 (M1) and for most of the years under method 2 (M2).

\footnotetext{
${ }^{5}$ We assume that the capital intensity (capital per unit labour) is the same as in case 1 . This means that for a Cobb-Douglas production function with constant return to scale the GDP decreases in proportion to the decreases in the total number of employed in the economy. The effect on GDP will be rather small because the number employed in the additional population is a small part of the number employed in the total population.
} 
Table 4 Fiscal effects of the additional population. SEK billion in four selected years. Case 1. *

\begin{tabular}{|c|c|c|c|c|c|c|c|c|}
\hline & \multicolumn{2}{|l|}{2015} & \multicolumn{2}{|l|}{2025} & \multicolumn{2}{|l|}{2035} & \multicolumn{2}{|l|}{2050} \\
\hline & M1 & $\mathrm{M} 2$ & M1 & M2 & M1 & M2 & M1 & $\mathrm{M} 2$ \\
\hline \multicolumn{9}{|l|}{$\begin{array}{l}\text { 1. Contributions to the } \\
\text { public sector (direct taxes, } \\
\text { indirect taxes }\end{array}$} \\
\hline $\begin{array}{l}\text { and social security fees) } \\
\text { 2. Sum of public transfers } \\
\text { and public consumption }\end{array}$ & 27.7 & 27.6 & 106.5 & 105.6 & 235.8 & 232.8 & 547.7 & 538.4 \\
\hline $\begin{array}{l}\text { expenditures } \\
\text { 3. Net contribution }\end{array}$ & 25.0 & 22.0 & 92.1 & 81.5 & 202.8 & 180.1 & 489.5 & 437.3 \\
\hline to the public sector $(1-2)$ & +2.7 & +5.6 & +14.4 & +24.1 & +33.0 & +52.7 & +58.2 & +101.1 \\
\hline 4. GDP & & 8.4 & & 6.1 & & 2.4 & & 7.1 \\
\hline 5.3 as a percentage of 4 & 0.08 & 0.16 & 0.33 & 0.55 & 0.61 & 0.97 & 0.77 & 1.34 \\
\hline
\end{tabular}

M1 $=$ method 1, M2 $=$ method 2

* The net contribution is the amount which the public sector redistributes between the additional population and the original population in respective year. The yearly net contribution will still be less than $1 \%$ for most of the years even if we as reference have used the share of GDP which arises from the original population. This share is more than 90 percent up to 2035. In 2050 it is somewhat less than 90 percent.

\subsection{Case 2}

The results are summed up in Table 5. Because of the less favourable labour market situation for the additional population compared to case 1, there are now negative yearly net contributions to the public sector. Also, in this case, the net fiscal effects are small and less than $1 \%$ of GDP for all years under M2 and for most of the years under M1.

Table 5 Fiscal effects of the additional population 2006-2050. SEK billion in four selected years.

Case 2.*)

\begin{tabular}{|c|c|c|c|c|c|c|c|c|}
\hline & \multicolumn{2}{|l|}{2015} & \multicolumn{2}{|l|}{2025} & \multicolumn{2}{|l|}{2035} & \multicolumn{2}{|l|}{2050} \\
\hline & M1 & M2 & M1 & M2 & M1 & M2 & M1 & M2 \\
\hline \multicolumn{9}{|l|}{$\begin{array}{l}\text { 1. Contributions to the } \\
\text { public sector (direct taxes, } \\
\text { indirect taxes }\end{array}$} \\
\hline $\begin{array}{l}\text { 2. Sum of public transfers } \\
\text { and public consumption }\end{array}$ & & & & & & & & \\
\hline $\begin{array}{l}\text { expenditures } \\
\text { 3. Net contribution }\end{array}$ & 26.3 & 23.4 & 96.5 & 85.9 & 212.8 & 190.2 & 507.8 & 459.0 \\
\hline to the public sector $(1-2)$ & -7.5 & -4.7 & -22.8 & -12.9 & -46.9 & -26.4 & -114.8 & -72.8 \\
\hline 4. GDP & & 15.0 & & 7.9 & & 2.7 & & 41.0 \\
\hline 5.3 as a percentage of 4 & 0.21 & 0.13 & 0.53 & 0.30 & 0.88 & 0.49 & 1.56 & 0.99 \\
\hline
\end{tabular}

$\mathrm{M} 1=\operatorname{method} 1, \mathrm{M} 2=\operatorname{method} 2$

* See table 4 


\section{Sensitivity analyses}

Let us use some other scenarios. Will these significantly change the results? Consider the alternatives below (Ekberg 2010).

1) We know that a share of the immigrants and their descendants move back to their home country. Let us assume a return pattern different from the one in the forecast by Statistics Sweden (2006). We can expect the most positive net fiscal effect if all immigrants and their descendants leave just before they reach the age of 65 . Of course this is an extreme scenario and unrealistic. Let us instead assume that so many individuals return back that the share in the additional population at ages above 64 is only half the share given in Table 1. If an individual leaves Sweden before age 65 he or she will have pensions from Sweden depending on the sum of their income from work during their time in Sweden. However, individuals who leave cannot use Swedish public consumption expenditures such as healthcare and services for pensioners and the disabled.

Calculations based on this assumption show a very small increase in yearly net contributions compared to the results the results in Table 4 and Table 5. Before 2035, the increase is less than $0.1 \%$ of GDP. It is at most $0.1 \%$ of GDP in 2035 at most $0.2 \%$ of GDP in 2050 . In case 1 the positive net fiscal effect will be in the range of $0.7-1.1 \%$ of GDP in 2035 and in the range of $0.9-1.5 \%$ of GDP in 2050. In Case 2, the negative net fiscal effect will be in the range of $0.4-0.8 \%$ of GDP in 2035 and in the range of $0.8-1.4 \%$ of GDP in 2050. For the years 2015 and 2025 the results will be about the same as in Table 4 and Table 5. We are still in the range $+/-1 \%$ of GDP for most of the years.

2) The contribution from the additional population to the public sector can depend on the composition of the public revenues, i.e. direct taxes from individuals, corporate taxes, indirect taxes and social security fees. As mentioned, the forecast is that the relative proportions of these revenues will change very little up to 2050 (Ministry of Finances 2008b). Let us assume that policy changes occur which increase the share of social security fees. This is a realistic alternative in a situation with an ageing population. We can expect the contributions to the public sector from the additional population to increase because the additional population is more concentrated in economically active ages than the original population. The base for social security fees is income from work. Let us assume that the share of social security fees increases over time from about $26 \%$ today to $30 \%$ in 2050 and that the contribution from direct taxes from hou seholds decreases to the same extent.

The increase in yearly net contributions from the additional population is also very small in this case compared to the results in Table 4 and Table 5. The increase is less than $0.1 \%$ of GDP for every year. Even if we let the share of social security fees increase to $35 \%$ in 2050 the change will be small (the contributions from direct taxes from the household decrease to the same extent). In that year, the increased net contribution will be only somewhat more than $0.1 \%$ of GNP and somewhat higher in case 1 than in case 2 . We are still in the range $+/-1 \%$ of GDP for most of the years.

3) Statistic Sweden (2006) assumes, in the projection used in this study, the same age-specific death rates and age-specific birth rates for the additional population as for the original population. There are studies which show somewhat higher age-specific death rates among foreign-born and their descendants born in Sweden (Albin, Ekberg, Elmeståhl and Hjelm 2006; Statistics Sweden 2010a). There are also studies which show 20\% higher age-specific 
birth rates among foreign-born in Sweden than among native-born (Statistics Sweden 2008b). An earlier study found $15 \%$ higher age-specific birth rates among foreign-born (Statistic Sweden 1975). However, these rates converge over time to about the same level as for native born. After 20 years the differences are about 10\% (Statistics Sweden 2009). Already in the second generation the age-specific fertility rates are even somewhat lower among descendants of immigrants than among natives with both parents born in Sweden (Statistics Sweden 2010a). In the additional population, the share of individuals born in Sweden increases over time. So, even if we take into consideration the differences in age-specific birth rates in the first generation it is reasonable to assume that the difference between the additional population and the original population will be smaller than $20 \%$ and especially in the long run the difference will be much smaller.

Some difference in death rates would be of small significance for the age composition of the additional population because this population is concentrated at ages with low death rates. Therefore, the change in net fiscal effects would probably be negligible. Differences in fertility rates would be of greater significance for the age composition because the additional population is more concentrated at fertile ages. Ekberg (1983) made a simulation of immigration to Sweden over a period of 60 years and its fiscal effects. The size and age composition of the additional population was estimated with the assumption of $15 \%$ higher age-specific birth rates in this population than in the original population. The age-specific employment rates were assumed to be the same for both. In this simulation, the share of young people in the additional population increased somewhat while there was a slight decrease in the share of working-age and old people compared to the case where the agespecific birth rates were the same for both populations. The impact of the higher birth rates on net fiscal effects was small. The tendency was in the direction of somewhat smaller positive net fiscal effects because of the lower share at working ages in the additional population. Thus, it is reasonable to believe that introducing an assumption in this paper of higher birth rates in the additional population than in the original population would somewhat decrease the positive net fiscal effect in case 1 and somewhat increase the negative net fiscal effect in case 2 . The net fiscal effect will still be in the range $+/-1 \%$ of GDP for most of the years.

4) In the projection used in this study it is assumed that public transfers and public consumption expenditures per capita will increase by $2.1 \%$ per year. The public sector in Sweden as share of GDP is already one of the largest in the world so it is not reasonable to assume that the increase will exceed $2.1 \%$. It will probably be lower. In the latest Long Term Survey of the Swedish Economy there is also an alternative with lower increase in public consumptions expenditures (Ministry of Finance 2008a, 2008b). In that case the public sector will be smaller and consequently both the positive net fiscal effect in case 1 and the negative fiscal effect in case 2 will be smaller. Thus, the net fiscal effect will still be in the range $+/-$ $1 \%$ of GDP for most of the years.

5) Greater net fiscal effects can be the outcome of much higher immigration. Let us assume that the migration inflow is so high that the additional population will be twice as high as in Table 1. In 2050 the additional population will, in that case, rise to 2.8 million individuals and the total population will reach 12.6 million. The economic growth will be higher because of the more rapid increase in the labour force. With the same age and sex composition at the time of immigration, the same age-specific birth rates and death rates and the same proportion of immigrants and their descendants leaving the country as given in the figures presented by Statistics Sweden (2006) the migration inflow will be about twice as high as in our former calculations. However, it would not prevent the total population from growing older. Such a 
high migration inflow is probably unrealistic but what will be its net fiscal effects? Our calculations show that they will be greater but still rather modest. In case 1 the positive net fiscal effect in 2050 amounts to $1.2-2.2 \%$ of GDP depending on M1 or M2. In case 2 the negative net fiscal effect in 2050 will be in the range of 2.0-3.0\% of GDP. In the years before 2050 both the positive and the negative net fiscal effects are smaller.

6) The fiscal impacts would be larger if future immigration could prevent the population from growing older. Statistics Sweden (2002) investigated the size of future immigration which is necessary to keep the share of over-64s in Sweden constant from today up to 2050. The conclusion is that immigration has to be unrealistically large and also increase over time. Immigration would be so massive that the population in Sweden would increase from 9 million individuals to about 16 million individuals in 2050, compared with somewhat more than 11 million in the more realistic case in Table 1. The question is also whether the Swedish labour market could adjust to such a large migration inflow. If not, negative fiscal impacts will probably arise.

\section{Summary and conclusion}

This paper has estimated the net fiscal effect up to 2050 of future immigration to Sweden. The conclusion is that the positive net fiscal effect will be small in relation to GDP even if future immigrants and their descendants born in Sweden are well integrated into the labour market. One reason for this is that future immigration increases the size of the population and thereby also increases public expenses. If future immigrants and their descendants are less well integrated into the labour market, having the same employment rate as foreign-born persons now living in Sweden, there will be a negative fiscal effect, but also small in that case. For most of the years the positive/negative net contribution to the public sector is less than $1 \%$ of GDP. This will be the case even if we change the assumptions concerning the composition of the tax system including social security fees, the growth of public consumption expenditures, return migration, and concerning age-specific birth rates and death rates. More considerable net fiscal effects would require a much higher and probably unrealistic level of immigration.

The situation can be different in countries where population ageing is more rapid than in Sweden. This will be the case in Germany, for example, and Italy, where the proportion of over-64s will probably exceed $30 \%$ by 2035 (Lutz, Marmolo \& Scherbov 2008). The positive net fiscal effect of future immigrants may be more considerable in these countries.

An alternative way of obtaining a positive net fiscal effect is to increase the employment rate among the immigrants already living in Sweden. The present employment rate for native Swedes aged 20-64 is somewhat more than $80 \%$. For foreign-born it is only $64 \%$ (Statistics Sweden $2010 b ; 2010 c)$. Let us assume that the employment rate for foreign-born increases by $10 \%$, i.e. by 6.4 percentage units. An estimation by Ekberg (2009) shows that this would be associated with a positive net fiscal effect amounting to $0.6 \%$ of GDP. This is almost equivalent to the positive net fiscal effect in 2035 in case 1 of this study and more than the positive net effects in the years before 2035. If more immigrants enter the labour market this could to some extent displace natives from the labour market. However, from the studies mentioned in the introduction we can conclude that the displacement effect is probably small. Thus, even a modest increase in the employment rate among foreign-born already living in Sweden will, for the next 20 years, produce a higher positive net fiscal effect than large-scale new immigration. The reason is that better labour market integration of immigrants already 
living in Sweden will not increase the population. Public transfer payments will decrease and public sector revenues from taxes and social security fees will increase. Thus, there is a potential to achieve rather large positive net fiscal effects by increasing the employment rates among foreign-born already living in Sweden.

Our results regarding fiscal effects of future immigration are based on projections which are static. However, the question regarding effects of immigration is complicated. Immigration can affect the destination country in many different ways. There may be general equilibrium effects which require complicated models to determine. For instance, it is possible that immigration affects economic growth i.e. affects GDP per capita which in its turn has fiscal impacts. A positive effect on economic growth can arise in different ways. Positive effects can be expected if the immigrants are high skilled, if they are more mobile than natives on the labour market, if they bring new ideas and if, by increasing population, they stimulate investment which acts as an incentive to the introduction of new technology. Positive fiscal effects arise from an increased base for taxes and social security fees. Conversely, immigration of unskilled persons may leads to weaker economic growth. Unskilled immigrants increase the labour supply in sectors with low-income industries, which can have an inhibiting effect on the development of new production methods in these industries and therefore hamper economic growth. As a consequence, negative fiscal effects arise. Poot and Cochrane (2005) present an overview of studies on immigration and economic growth. Different studies give different answers. For Sweden, a model with endogenous technical progress has been used (Ekberg 1983). According to the model, the effect on economic growth was very small. However, more research on this topic is required. A challenge for future research on fiscal impacts of immigration is to construct models which also consider general equilibrium effects of immigration.

\section{References}

Akbari, A.H. (1989), The benefits of immigrants to Canada: Evidence on tax and public services. Canadian Public Policy, 15(4), 424-435.

Albin, B., Ekberg J., Elmeståhl S. \& Hjelm, K. (2005), Mortality among foreign-born and native-born Swedes. European Journal of Public Health, 15(5), 511-517.

Ben-Gad, M. (2004), The economic effects of immigration-a dynamic analysis. Journal of Economic Dynamics and Control, 28(9), 1825-1845.

Blau, F.D. (1984), The use of transfer payments by immigrants. International Labour Relations Review, 37 (2), 222-239.

Bonin, H., Raffelhuschen, B., \& Walliser, J. (2000), Can immigration alleviate the demographic burden? FinanzArchiv, 57(1), 1-21.

Borjas, G. J. (1994), The economics of immigration. Journal of Economic Literature, 32(4), 1616-1717.

Coleman, D. \& Rowthorn, R. (2004). Effects of immigration into the United Kingdom. Population and Development Review, 30(4), 579-622.

Coleman, D. (2009). The demographic effects of international migration in Europe. Oxford Review of Economic Policy, 24(3), 453-477.

Ekberg, J. (1983). Inkomsteffekter av invandring. (Income effects due to immigration). PhDthesis in Economics Lund University. Lund Economic Studies, no 27. Lund. (Summary in English).

Ekberg, J. (1999). Immigration and the public sector. Income effects for the native population in Sweden. Journal of Population Economics, 12(3), 411-430.

Ekberg, J., \& Rooth, D-O. (2001). Är invandrare oprioriterade inom arbetsmarknadspolitiken? 
(Are immigrants not giving priority to labour market policy programmes?). Ekonomisk Debatt, 28(4), 285-291.

Ekberg, J. (2009). Invandringen och de offentliga finanserna. (Immigration and the public finances). (Summary in English). Rapport 2009:3 to the Expertgroup for public finances (ESO). The Ministry of Finance . Stockholm.

Ekberg, J. (2010). Effekter för offentliga finanser vid alternativa scenarier beträffande framtida invandring (Effects on public finances with alternatives scenarios of future immigration). Paper. Linne University. Växjö.

Försäkringskassan. (2007). Socialförsäkringsboken 2006 (Social security book 2006). Stockholm.

Gieseck, A. Heilemann, V., \& Loeffelholz, H. (1994). Economic implications of migration into the Federal republic of Germany 1988-1992. In Spencer S (ed.) Immigration as an economic asset. Trentham books. Staffordshire.

Gustafsson, B. (1990). Public sector transfers and income taxes among immigrants and natives in Sweden. International Migration, 28(2),181-200.

Gustafsson, B., \& Österberg, T. (2001). Immigrants and the public sector-accounting exercises for Sweden. Journal of Population Economics, 14(4), 689-708.

Kakwani, N. (1986). Analysing redistribution policies. A study using Australian data. Cambridge University Press. Cambridge.

Korpi, M. (2008). Migration and wage inequality: Economic effects of migration to and within Sweden 1993-2003. Working Paper Series no 2008:13. Institute for future studies. Stockholm.

Lee, RD., \& Miller, T. (2000). Immigration, social security and broader fiscal impacts. American Economic Review, 90 (2), 350-354.

Longhi, S., Nijkamp, P., \& Poot, J. (2005). A meta-analytic assessment of the effect of immigration on wages. Journal of Economic Surveys, 19(5), 451-477.

Longhi, S., Nijkamp, P., \& Poot, J. (2006). The fallacy of 'job robing': A meta-analysis of estimates of the effect of immigration on employment. Journal of Migration and Refugee Issues, 1(4), 131-152.

Longhi, S., Nijkamp. P., \& Poot, J. (2008). Meta-analysis of empirical evidence on the labour market impacts of immigration. Discussion Paper Series no 3418. The Institute for the Study of Labor (IZA). Bonn.

Lutz, W., Marmolo, M., \& Scherbov, S. (2008). Probalistic population projections for the 27 EU member states. Paper at 2008 European population Conference, 9-12 July Barcelona. Spain.

Ministry of Finance. (1990). The medium term survey of the Swedish economy. SOU 1990:14. Allmänna Förlaget. Stockholm.

Ministry of Finance. (2008a). Långtidsutredningen 2008. (Long term survey of the Swedish economy 2008). SOU 2008:105. Fritzes. Stockholm.

Ministry of Finance. (2008b). Scenarier på lång sikt. Bilaga 1 till långtidsutredningen 2008 (Scenarios in the long run. Supplement 1 to the Long term survey of the Swedish economy 2008). SOU 2008: 108. Fritzes. Stockholm.

Ohlsson, R. (1975). Invandrarna på arbetsmarknaden (Immigrants in the labour market). $\mathrm{PhD}$-thesis in Economic History. Lund University. Ekonomisk-historiska Föreningen, Vol XVI. Lund. (Summary in English).

Pedersen, L. H. (2002). Ageing, immigration and fiscal sustainability. DREAM. Copenhagen, mimeo.

Poot, J. \& Cochrane, B. (2005). Measuring the economic impact of immigration: A scoping paper. Discussion Paper no 48. Population Studies Centre. The University of Waikato. Hamilton. 
Rowthorn, R. (2008). The Fiscal impact of immigration on the advanced economies. Oxford Review of Economic Policy, 24(3), 561-589.

Schou, P. (2006). Immigration, integration and fiscal sustainability. Journal of Population Economics, 19(4), 671-689.

Simon, J. (1984). Immigrants, taxes and welfare in the United States. Population and Development Review, 10(1), 55-69.

Statistic Sweden. (1975). Sveriges befolkningsutveckling (The population development of Sweden). Information i prognosfrågor 1975:6. Stockholm.

Statistics Sweden. (2002a). Kapital inkomster (Incomes from capital) Inkopak 2002. Stockholm.

Statistic Sweden. (2002b). Invandring-en lösning på försöjningsbördan? (Immigration - a solution on increasing dependency ratio?). Demografiska rapporter 2002:6. Stockholm.

Statistics Sweden. (2004). Efterkrigstidens invandring och utvandring (Immigration and emigration during the postwar period). Demografiska rapporter 2004:5. Stockholm.

Statistics Sweden. (2006). Sveriges framtida befolkning 2006-2050 (The future population in Sweden 2006-2050). Demografiska rapporter 2006:2. Stockholm.

Statistics Sweden. (2007). Arbetskraftsundersökningarna 2006 (Labour force surveys 2006). Stockholm.

Statistics Sweden. (2008a). Specialbeställd data över inkomster, skatter och offentliga transfereringar år 2006 för infödda och utrikes födda (Specially delivered data about incomes, taxes and public transfers in 2006 for native-born and foreign-born). Stockholm.

Statistics Sweden. (2008b). Barnafödandet bland inrikes och utrikes födda (Childbearing among natives and foreign-born). Demografiska rapporter 2008:2. Stockholm.

Statistic Sweden. (2009). Sveriges framtida befolkning (The future population of Sweden). Demografiska rapporter 2009:1. Stockholm.

Statistics Sweden. (2010a). Födda i Sverige men ändå olika. Betydelsen av föräldrarnas födelseland (Born in Sweden-but still different? The significance of parents country of birth). Demografiska rapporter 2010:2. Stockholm.

Statistics Sweden. (2010b). Arbetskraftsundersökningarna 2009 (Labour force surveys 2009). Stockholm.

Statistics Sweden. (2010c). Arbetskraftsundersökningarna andra kvartalet 2010 (Labour force surveys the second quarter of 2010). Stockholm.

Storesletten, K. (2003). Fiscal implications of immigration to Sweden-a net present value calculation. Scandinavian Journal of Economics, 105(3), 487-506.

Straubhaar, T., \& Weber, R. (1994). On the economics of immigration: some empirical evidence for Switzerland. International Review of Applied Economics, 8(2), 107-129.

The Swedish Audit Bureau. (2007). Regeringens analys av finanspolitikens långsiktiga hållbarhet. (The Government's analysis of long run persistency of finance policy). Rapport RIR 2007.21. Stockholm.

Ulrich, R. (1994). The impact of foreigners on public purse. In Spencer S (ed.) Immigration as an economic asset. Trentham Books. Staffordshire.

Wadensjö, E. (1973). Immigration och samhällsekonomi. (Immigration and economy). PhDthesis in Economics Lund University. Lund Economic Studies no 8. Lund. (Summary in English).

Wadensjö, E. (2000). Omfördelning genom offentlig sektor: En fördjupad analys. (Redistribution through public sector. A deeper analysis). In Mogensen G (ed.)

Integration i Danmark omkring årtusendskiftet. (Integration in Denmark around the turn of millennium). Aarhus universitetsforlag. Aarhus.

Wadensjö, E., \& Orrje, H. (2002), Immigration and the public sector in Denmark. Aarhus 
universitetsforlag. Aarhus.

Weintraub, S. (1984). Illegal immigrants in Texas: impact on social services and related considerations. International Migration Review, 18(3), 733-747.

\section{Appendix}

Table A. Age composition of the additional population in percent due to future immigration. The years 2015, 2025, 2035, and 2050 .

\begin{tabular}{lllll}
\hline Age & 2015 & 2025 & 2035 & 2050 \\
\hline $0-6$ & 13.8 & 14.2 & 11.5 & 10.2 \\
$7-15$ & 11.6 & 12.8 & 14.0 & 12.6 \\
$16-19$ & 4.5 & 4.7 & 5.6 & 5.4 \\
$20-24$ & 8.6 & 6.7 & 6.9 & 7.1 \\
$25-34$ & 27.8 & 21.0 & 16.9 & 15.9 \\
$35-44$ & 18.2 & 20.0 & 17.8 & 15.0 \\
$45-54$ & 8.5 & 11.3 & 13.9 & 13.0 \\
$55-64$ & 4.1 & 5.4 & 7.7 & 10.6 \\
$65-74$ & 2.1 & 2.7 & 3.8 & 6.5 \\
$75-$ & 0.7 & 1.2 & 1.9 & 3.7 \\
Total & 100.0 & 100.0 & 100.0 & 100.0 \\
Number of & & & & \\
individuals & 164,373 & 475,906 & 834,562 & $1,397,816$ \\
\hline
\end{tabular}

Sources: Statistics Sweden (2006) and special data from Statistics Sweden. 